\title{
The Political Economy of Extraterritoriality
}

\author{
Paul B. Stephan
}

School of Law, University of Virginia, 580 Massie Road, Charlottesville, VA 22903-1738, USA;

E-Mail: pbs@virginia.edu; Tel.: +1 4349247098; Fax: +1 4349247536

Submitted: 10 April 2013 | In revised form: 30 April 2013 | Accepted: 14 May 2013 |

Published: 4 June 2013

\begin{abstract}
Near the end of the 2009 Term the Supreme Court decided Morrison v. Australia National Bank, Ltd., the strongest anti-extraterritoriality opinion it has produced in modern times. Not only is Congress presumed generally to prefer only territorial regulation, but lower courts that had carved out exceptions from this principle over a long period of time must now revisit their positions. Again this year in Kiobel v. Royal Dutch Shell Co. the Court relied on an aggressive use of the presumption against extraterritoriality to cut back on an important field of private litigation. The Court appears to have embraced two related stances: The imposition of barriers to extraterritorial regulation generally advances welfare, and the lower courts cannot be trusted to determine those instances where an exception to this rule might be justified. Implicit in the Court's position are intuitions about the political economy of both legislation and litigation. I want to use the occasion of the Morrison and Kiobel decisions to consider the political economy of extraterritorial regulation by the United States. International lawyers for the most part have analyzed state decisions to exercise prescriptive jurisdiction over extraterritorial transactions in terms of a welfare calculus that determines the likely costs and benefits to the state as a whole. Fewer studies have considered the political economy of the decision whether to regulate foreign transactions. No work of which I am aware has considered the political economy of deciding the extraterritorial question through litigation. This paper seeks to fill these gaps by sketching out what political economy suggests both about extraterritoriality and the role of courts as arbiters of extraterritoriality.
\end{abstract}

Keywords: international economic regulation; political economy of litigation; political economy of regulatory jurisdiction; regulatory jurisdiction 


\section{Introduction}

One sign of the United States' arrival as an international hegemon was the imposition of its economic regulation on foreign actors and transactions. Breaking with a tradition that had limited regulatory authority (prescriptive jurisdiction) to a state's territory and subjects, the United States at the end of World War II claimed the right as well as the capacity to regulate any transaction in which it had an interest [1]. Australia, Canada and the European powers pushed back, but failed to reverse this stance. Dynamic tension ensued. In 1988 the European Court of Justice accepted that EC competition rules could apply to overseas conduct [2]. Extraterritoriality of regulation has become a fact of life, albeit a controversial one.

The stakes are considerable. On the one hand, a state that fails to regulate offshore production of goods and services might allow its consumers to suffer (what it considers) injuries and its producers to lose international market share to under-regulated competitors. On the other hand, a state might impose offshore regulation to deprive foreign producers of an otherwise legitimate competitive advantage. They even can use regulation as a form of trade protection by imposing stricter standards on foreign firms than on domestic producers. There is every reason to think that national interest rather than global welfare will dominate what choices states make (see [3]).

Determining whether extraterritorial regulatory authority exists involves a complex dynamic among the three branches of government. The legislature must create regulatory authority, in the course of which it may or may not address the extraterritoriality issue. The executive, as either the exclusive regulator or in partnership with private litigants, may make assertions about the scope of authority. Courts will adjudicate claims made by both the executive and private actors. The pronouncement of courts in turn will inform the legislature about the kinds of signals it must send to permit extraterritorial regulation.

In 1991, the Supreme Court in EEOC v. Arabian American Oil Co. (Aramco) sought to clarify the law [4]. The decision articulated a presumption against extraterritoriality, making it more costly for Congress to authorize such regulation. In 2011, the Court, in Morrison v. Australia National Bank, Ltd., issued an even stronger anti-extraterritoriality opinion [5]. Not only was Congress presumed generally to prefer only territorial regulation, but lower courts that had carved out exceptions from this principle over a long period of time had to revisit their positions. Most recently, the Court in Kiobel v. Royal Dutch Shell invoked the presumption in a context that some (including four members of the Court) think inapposite, namely the application of international human rights law [6]. The last case repudiated a wide swathe of circuit court decisions [7].

Three data points may not support much social science, but lawyers and policy makers must cope as best they can. The Court appears to have embraced two related stances: The imposition of barriers to extraterritorial regulation generally advances welfare, and the lower courts cannot be trusted to determine those instances where an exception to this rule might be justified. Implicit in the Court's position are intuitions about the political economy of both legislation and litigation.

I want to use the occasion of the Morrison and Kiobel decisions to consider the interests that produce extraterritorial regulation by the United States. International lawyers and international relations scholars for the most part have analyzed state decisions to exercise prescriptive jurisdiction over extraterritorial transactions in terms of a welfare calculus that determines the likely costs and benefits to the state as a whole (e.g., [8,9]). Fewer studies have considered the political economy of the decision whether to regulate foreign transactions [10]. No work of which I am aware has considered the political economy of deciding the extraterritorial question through litigation [11]. This paper seeks to fill these gaps by sketching out what political economy suggests both about extraterritoriality and the role of courts as arbiters of regulatory scope.

\section{The Political Economy of Extraterritorial Regulation}

The conventional international political economy story starts with a strong assumption about states as internally homogenous actors. This "black box" approach posits national interests that states pursue in interactions with other states. Within this framework, states have incentives to pursue two general policies: to export their own negative externalities and to resist the importation of other states' negative externalities. Antitrust provides convenient examples: A state may encourage export cartels by its producers even as it punishes anticompetitive conduct by external actors that affect its economy. Confronted with these conflicting interests, a state has to pick a rule that maximizes the sum of protection for its export activities and authorization of its capacity to regulate unwanted imports. A country that only exports would opt for a strong rule against extraterritorial regulation. A state that imports goods that are likely to be cartelized might want the authority to regulate offshore producers (see [9], supra note 6).

A more sophisticated political-economy analysis would disaggregate the state to identify the discrete interests of institutional actors within the state sector. It would go beyond estimating overall national welfare to assess the interests of particular influential groups in the outcome of regulatory choices. A conventional model of U.S. political economy, for example, depicts the Executive as relatively more sensitive to foreign influences, including those of foreign producers represented by their states. The Executive is in an iterative 
game with foreign governments that opens the possibility for solving collective action problems. Senior policymakers within the Executive also are mostly political appointees that serve for relatively brief periods and thus are subject to revolving-door pressures. Foreign economic interests are likely to be in the mix of subsequent bidders for their services [12-14].

The Congress is more sensitive to domestic producers due to well recognized public choice effects. Producers tend to be local, concentrated, and homogenous in their interests, leading to natural alliances with their representatives in Congress. Consumers are dispersed and heterogeneous in their interests, raising organizational costs and impeding their ability to wield political influence. Moreover, members of Congress represent local rather than national constituencies, rendering these legislators less sensitive to general national interests. Legislators face no penalty at the polls when they pander to local hostility to foreign interests, and receive no reward when they pursue balanced policies that incorporate the interests of foreigners. In addition, because Congress does not have a permanent bureaucracy, or at least has much less of one than does the Executive, its capacity to participate in iterative interactions with foreign states is more limited. Finally, the leadership of Congress and their staff turn over less frequently than do senior Executive officials, diluting the revolving door effect compared to their Executive-branch counterparts. The net effect should be a body sensitive to the concerns of domestic producers, insensitive to the concerns of domestic consumers, and largely indifferent to the welfare of foreign producers and consumers.

Applying this simple, indeed rudimentary, model to decisions about extraterritorial regulation, one would predict that Congress would push both for immunity for domestic producers from foreign regulation and for extraterritorial application of U.S. regulation. The argument for the immunity is easy. Domestic producers would argue that foreign regulation is discriminatory and harmful to U.S. interests. The argument for extraterritorial extensions of U.S. regulation would rest on the assertion that foreign producer behavior undercuts U.S. producers both at home and abroad and also endangers U.S. consumers. Congress would have no particular reason to act consistently, as foreign interests do not participate in their elections. Moreover, because it lacks foreign interlocutors to challenge its choices, it would not focus on the indirect costs of such inconsistency, such as foreign retaliation against U.S. exporters.

The model predicts that the Executive would push back against these proposals. The ability of local producers to capture strong advocates in Congress does not translate into the same pressures on the Executive. The Executive should focus most on groups with effective power in marginal, large-electoral vote states. Moreover, the Executive must engage with foreign governments, and components of the Executive, not least the President himself, will be judged based on outcomes over which foreign governments have some influence. Finally, the Executive has a substantial permanent bureaucracy that interacts with foreign governments and wishes their exchanges to go smoothly. The bureaucrats, as well as senior Executive officials, might enjoy subsequent careers in the private sector working on behalf of foreign interests. For all these reasons, the Executive will be more sensitive to concerns about consistency than will Congress. It, rather than Congress, will confront the contradiction inherent in extending extraterritorial regulation while defending domestic producers from foreign regulation.

Anecdotal evidence is consistent with these conjectures. Initiatives to expand extraterritorial regulation tend to come from Congress. In trade law, Congress is a perennial source of protectionist measures, which the Executive tends to resist.

Examples of the tension between Congress and the Executive over protectionism, albeit not precisely in the form of extraterritorial regulation, include the 2000 Byrd Amendment, which increased the incentive of domestic producers to seek antidumping and countervailing duties on imports and which the Clinton Administration unsuccessfully battled, and the 2007 broadening of Exon-Florio regulation of inbound investment following the Dubai Ports World kerfuffle, which the Bush II Administration unsuccessfully resisted [15]. Both these measures restricted imports (goods in the case of the Byrd Amendment, capital in the case of the Dubai Ports World legislation) in ways that invite retaliation and probably reduce overall U.S. welfare. The laundry list of protectionist legislation that never gets out of Congress, often because of Executive opposition, is extensive and well known. A more systematic review of the evidence, I suspect, would produce conclusions broadly consistent with the simple model, but I do not pretend to have conducted that study.

Finally, courts have complex incentives. One might postulate two general forces shaping their preferences. First, one would expect some correlation between their policy preferences and those of the President who selected them. Second, judges react to litigation and the way it frames choices as much, if not more, as they proactively seek to shape legal policy. One, thus, would anticipate some influence over their choices by litigants that appear before them.

It seems plausible that the effect of Presidential preferences on judicial behavior might increase as one moves up the judicial hierarchy. While personnel in the Executive might investigate the careers of judicial candidates to predict future voting behavior, they would know that such research is costly relative to the value of the data derived. It is notoriously difficult to predict the future voting patterns of judges, especially with respect to issues that may become important but have not yet arisen (the known unknowns). The willingness of the Executive to incur these costs likely 
increases with the importance of the position. Accordingly, the odds that a judge will vote consistently with the preferences of the nominating President may increase as one goes up the hierarchy, with Supreme Court nominees subject to the greatest investment in selection [16].

Conversely, one would expect the effect of litigant framing to be greatest in the lower courts. First, federal district courts and courts of appeals, unlike the Supreme Court, have no control over their docket. Second, lower federal judges tend to have strong local ties, including repeat interactions with the lawyers who bring suits. Third, relative to the Supreme Court, lower federal judges have fewer resources to conduct independent research into the matters before them, and thus rely more heavily on the representations of the lawyers in particular cases. Lower court judges both see more cases and have fewer staff. In particular, their law clerks come out of a less competitive process and generally have no prior legal experience, while Supreme Court clerks attain their position after great competition and typically have a year or more of legal work before they come to their posts.

These conjectures about influences on judicial decisionmaking support several hypotheses. First, they imply that litigant choices will have a greater influence on the lower courts. Executive branch screening will be weakest at the lower levels of the judiciary, and judges will have more extensive contacts with the local bar. Accordingly, ceteris paribus, lower courts, compared to the Supreme Court, are more likely to produce outcomes that litigating lawyers favor. The Supreme Court, with greater control over its docket and, by tradition, always sitting en banc, might act more on the basis of the median policy preferences of the Justices. Under the normal structure of litigation, the lower courts get the first opportunity to address open legal questions, with the Supreme Court choosing the moment when to intervene and bless or correct the path taken. Accordingly, one might predict gradual expansion of regulatory jurisdiction, including extraterritorial extensions, through lower court decisions, with episodic resistance by the Supreme Court.

In different government structures, of course, different dynamics can result. The European Community, for example, lacks a popularly elected executive, the function of its Parliament is more complicated, and its mechanism for judicial selection and choice of judicial structure is completely different from that of the United States. Accordingly, much of this informal model is inapplicable. Thus my conjectures are limited to the United States, although specialists in comparative government might find ways of revising and extending them to other systems (cf. [17]).

\section{The Morrison Case}

The conjectures, if nothing else, resonate with the particular story of securities-law extraterritoriality. The statutory provision at issue, Section 10(b) of the Securities Exchange Act of 1934, authorizes the Securities and Exchange Commission (SEC) to issue regulations defining sanctionable misbehavior in connection with the purchase or sale of a security [18]. The U.S. Court of Appeals for the Second Circuit and its district courts play an outsized role in securities litigation, largely due to the presence of the country's leading financial center in their jurisdiction. The history of securities litigation hence is largely a story of the relationship between the Second Circuit and the Supreme Court.

In 1942 , the SEC promulgated Rule 10b-5, which broadly prohibits fraudulent or deceptive practices in connection with the purchase or sale of a security [19]. In 1946 a federal district court ruled that victims of 10b-5 violations may bring suit in their own right for compensation, and later lower court decisions coalesced around this result [20]. Class actions suits based on Rule 10b-5 took off in the mid-1960s, and in 1968 the Second Circuit in Schoenbaum v. Firstbrook [21] ruled that actions in Canada that affected the market price of securities sold in the United States fell within 10b-5's scope. Judge Lumbard, the author of that decision, had worked in securities regulation before joining the bench and, his opinions indicate, generally preferred expanding the scope of that regime. Three Second Circuit decisions in the early 1970s, all written by Judge Friendly, both more famous and more conservative than Lumbard, moderated Schoenbaum by limiting regulatory scope to instances where foreign actions had a direct effect on a U.S. victim (and not simply an effect on the market) or a perpetuation of fraud affecting a foreign transaction involved substantial conduct on U.S. territory [22-24].

So the law stood, with insignificant variations in other Circuits, until Morrison. That case involved Australian investors in an Australian company that sought compensation for injuries resulting from the company's misleading statements about certain transactions undertaken in the United States. The Second Circuit, applying its case law, ruled that the alleged misconduct fell outside the scope of U.S. jurisdiction. The Supreme Court, while affirming the result, effectively spanked the Second Circuit for its legal analysis. It held that Section 10(b) and Rule 10b-5 applied only to sales transactions that take place on U.S. territory or (less clearly) involving securities registered in the United States under the Securities and Securities Exchange Acts [25].

The Second Circuit approach generally benefitted lawyers by employing vague standards to determine the extraterritorial scope of U.S. regulation. The openended effects and conducts tests increase the need for legal services at both the planning and dispute resolution stages. Moreover, while the rule might have been suboptimal for some clients of the defense bar, its effects on them were mixed. While vague extraterritoriality produced a heightened regulatory burden on 
U.S. financial institutions involved in foreign transactions, it imposed at least as large costs on some of their foreign competitors. There is every reason to believe, in short, that lawyers in general liked the Second Circuit approach, because it benefitted them directly and substantially and had only mixed effects on their clients. The Supreme Court's intervention in turn can be interpreted as policy-driven and consistent with other efforts of that Court to constrain litigationfriendly behavior by lower courts [26].

\section{Alien Tort Litigation}

The alien tort litigation saga also resonates with my informal model. These cases first appeared in 1980, although the so called Alien Tort Statute (ATS), the measure on which they rest, is much older [27]. The earliest suits attacked foreign government officials and others who wielded state power to commit atrocities against a local population. Beginning in the late 1990s, however, plaintiffs began going after multinational corporations, not all based in the United States, that operate in areas where civil conflict has unfolded or brutal and oppressive regimes otherwise have terrorized the local population. The cases rest on the theory that a U.S. court would provide a remedy for any violation of international law that constituted a tort and injured an alien [28].

As with securities fraud litigation, the ATS suits gained support from sympathetic lower federal courts, punctuated by occasional Supreme Court resistance. In 2004 the Supreme Court in Sosa v. Alvarez-Machain admonished the lower courts to limit the range of international law obligations to which this statute could apply, but the scale, if not the scope, of suits in the lower courts continued to grow [29]. The Court returned to the fray in Kiobel. A majority maintained that the presumption against extraterritoriality as expounded in Morrison applied to alien tort suits. Because the case involved Nigerian victims of atrocities that took place in Nigeria and were said to have been procured by an Anglo-Dutch company, the ATS could not provide a remedy. In general, the Court declared, foreign events can give rise to an ATS suit in U.S. courts only when a claim touches and concerns the territory of the United States "with sufficient force to displace the presumption against extraterritorial application" [30].

The Kiobel dissenters did not believe that the presumption has anything to do with a statute that enforces international legal norms. Rather, they would authorize a tort suit wherever the case involved either a U.S. defendant or "an important American national interest" [31]. Foremost in the latter category would be instances where a person sought refuge in the United States after committing a grave violation of international human rights law. Even these justices, however, rejected that idea that victims of human rights violations anywhere in the world generally could seek justice through an ATS suit.

The alien tort regime that Kiobel circumscribed, like the securities regulation regime cut back in Morrison, was great for plaintiffs' attorneys, had mixed effects on defense counsel, and clearly was adverse to the interests of foreign corporations. From the late 1990s on, plaintiffs' attorneys saw alien tort suits against wealthy defendants as a new growth opportunity in the wake of other cutbacks on tort litigation in the United States. Counsel who represented U.S. corporate defendants welcomed the work but also respected their clients' preference not to be sued. Were suits to proceed, however, these clients did want maximum exposure for their foreign competitors. Only foreign defendants, both wealthy individuals and businesses, had an unmitigated desire to bar these suits. As with Morrison, then, the lower courts' relatively permissive approach to alien tort litigation coincided with the general preferences of the litigating bar, while the Supreme Court's Kiobel decision reflects the policy preferences of the Court's majority.

\section{The Political Economy of the Choice of Mechanisms to Determine Extraterritoriality}

In the prior section I focused on the incentives facing Congress, the Executive and the judiciary in deciding whether to extend regulation extraterritorially. One can use these factors to analyze potential mechanisms for choosing extraterritorially. By mechanism, I mean the rules constraining the process that determines whether a particular regulatory regime will have any extraterritorial effect. To simplify, I describe three types of mechanisms-a clear statement of extraterritoriality by Congress, a clear statement by the Executive based on a delegation of authority by Congress, and extension by private litigation. The choice of mechanism involves both different political economies and, I will argue, significantly different welfare effects.

Given the political economy of extraterritoriality discussed in the prior section, one would expect to observe significant extraterritorial regulation expressly adopted by Congress. Congress will exert maximum effort to benefit domestic producers, and the Executive will resist such protection only intermittently. Even under a clear statement regime, one would expect many instances of an extraterritorial regulatory regime.

Casual empiricism confirms this conjecture. U.S. legislation has more express extraterritoriality than one usually encounters in national laws. U.S. tax law, for example, contains more outbound taxation-taxes on overseas capital and transactions-than one sees in most rich countries. First, as to individuals, the United States is almost alone in taxing the worldwide income of all its citizens, not just its residents [32]. Second, as to corporations, Subpart F contains aggressive rules for imputing the income of foreign subsidiaries to U.S. parents [33]. As best I can tell, other countries do not have as strong a regime for re- 
sourcing income of a foreign corporation as domestic income. This example is significant because taxation arguably is the most pervasive and salient form of national regulation. Taxation of overseas transaction in effect punishes firms that employ offshore production, and thus conforms to the interest of domestic producers.

Taxation aside, Congress has had no difficulty adopting laws that expressly extend U.S. regulation overseas. One is tempted to infer that Congress still believes that the United States enjoys the same economic hegemony it wielded back in 1945 . Numerous examples exist. Although the effects doctrine in antitrust was developed judicially, Congress codified this development in 1982 [34]. The Foreign Corrupt Practices Act regulates the bribery of only foreign persons, albeit with other jurisdictional requirements [35]. EEOC v. Arabian American Oil Co. contains a lengthy list of other statutes with express extraterritorial effect [36]. Congress responded to the last case almost immediately with an express, if limited, extension of extraterritorial regulation [37].

The puzzle, if there is one, is why Congress does not do this more often. The answer, it appears, is resistance from the Executive, which channels foreign governmental pressure as well the concerns of U.S.based multinational firms. The Byrd Amendment of 2000 illustrates the dynamic: A locally interested Senator exploited the Senate's procedures to insert a provision in a bill that the President could not veto. The President obtained repeal several years later in the wake of international retaliation [38]. The consistent opposition of the Bush II and Obama Administrations to congressional efforts to impose sanctions on China for its currency policies offers another example. The Executive's resistance has delayed these measures for years.

What one sees less frequently is delegation by Congress to an agency of the Executive of discretion to extend regulation extraterritorially. In trade law, a possible example is Title III of the Trade Act of 1974, which gives the Executive authority to sanction states for overseas conduct that affects the interests of U.S. exporters [39]. Even this example is complicated, however, as Congress in 1988 sought to make this tool nondiscretionary in specified instances. Informal rather than formal sanctions attached to the Executive's refusal to exercise this authority, and in practice no confrontations between the branches occurred. In 1994 Congress modified Title III by nesting it within the Executive's authority to seek WTO dispute resolution. At least when the malefactor belongs to the WTO (as does almost every significant exporter, including now even Russia), the Executive thereby acquired significant control over the sanctioning process.

A different instance of a delegation involves Section 929P(b) of the Dodd-Frank Wall Street Reform and Consumer Protection Act. Congress apparently intended to modify the holding of Morrison by giving the
SEC and the Department of Justice, but not private plaintiffs, the authority to sanction extraterritorial violations of Rule 10b-5 [40]. In effect the statute leaves it to the exclusive discretion of the Executive to determine when the Securities Exchange Act might apply extraterritorially and limits sanctions to those that the Executive can seek [41].

At first glance the relative paucity of delegations seems surprising. Congress has at least one clear incentive to delegate regulatory authority to the Executive: After delegation, influential Members then can lobby the agencies on behalf of interested persons (see [42]). Perhaps the reason for the paucity is that extraterritoriality is different. Congress might believe that the Executive is especially susceptible to foreign pressure and therefore an untrustworthy delegate with respect to this issue. Even clear legislative statements of extraterritoriality run up against the Executive's prosecutorial discretion, as illustrated by the current version of Title III of the Trade Act of 1974. Congress might believe that expressly endorsing the Executive's power not to act serves no useful purpose.

The third mechanism for choosing to regulate extraterritorially is to leave the question to the courts. This approach requires legislation that does not advert clearly to the issue and judicial willingness to fill the statutory gap with a rule that permits at least some extraterritorial application. The now repudiated securities law decisions in the Second Circuit and the host of lower-court ATS cases illustrate this approach, as does the pre-1982 judicial interpretation of the Sherman Act. Other instances where the lower courts currently assume responsibility for determining extraterritoriality in the absence of clear approval from the Supreme Court include civil RICO (see [43-46].

The previous section sketches out some reasons why lawyers would prefer this approach but persons at risk of regulation might not. Delegations to the judiciary to determine extraterritoriality result in caseby-case lawmaking. Vague standards, the inevitable product of judicial management of competing policy claims, invite litigation, which lawyers like and clients do not. In some industries, the cost of the legal risk might be offset by the prospect that foreign competitors will face the same, and perhaps even greater, costs once regulation is exported. Within the judiciary, resistance to this mechanism comes mostly from the Supreme Court, where Justices have greater freedom to pursue their policy preferences and are less hostage to the agenda-setting of litigants than are lower court judges.

One suspects that, even if extraterritorial regulation has net benefits for some domestic producers, they would prefer the decision to come through the legislative process (see [47]). Extraterritorial extension achieved through case-by-case decisionmaking entails considerable uncertainty. The extension is never absolute, but subject to a fact-specific test such as the direct-effects standard. The standard increases risk along 
several dimensions. A domestic producer cannot be confident when it can escape regulation or when its competitors will be sanctioned. Moreover, as long as any one regulatory statute generates judicial extraterritorial extension, there remains a threat that other statutes might generate similar outcomes. The uncertainty about application thus extends across a range of statutory regimes.

Another factor in the mix is the Executive. On the one hand, at least some administrations internalize the interests of litigators, at least to some extent. The Obama Administration, through an amicus brief, defended the approach of the Second Circuit under the Securities Exchange Act [48]. It also persuaded the Solicitor General in its Kiobel amicus brief to back away from its earlier strong opposition to extraterritoriality [49]. On the other hand, the Executive sometimes prefers to have a monopoly over regulation rather than competing with private attorney generals. Private competition undermines the ability of the Executive to bargain for cooperation through plea bargains, because then the Executive cannot immunize defendants from civil liability sought directly by victims. This dynamic exists in all regulatory schemes, but the stakes go up when extraterritoriality is involved. Where foreign application exists, private liability disrupts the bargains not only of domestic regulators, but of foreign regulatory authorities as well. This disruption in turn impedes international regulatory cooperation in other areas, such as sharing of intelligence. The Bush II Administration relied on this argument in F. Hoffman-LaRoche Ltd. v. Empagran S.A., where is successfully persuaded the Court to limit standing under the Foreign Trade Antitrust Improvements Act so as to limit private competition with public extraterritorial enforcement [50].

The relative skepticism of the Executive toward judicial management of the extraterritorial scope of regulation also might explain why the Supreme Court pushes back against legislation that invites but does not command extraterritorial application. As noted above, the Executive invests more in the selection of Supreme Court justices, who in turn are less influenced by the preferences of the litigating bar than are lower court judges. It is plausible that skepticism about Congressional efforts to smuggle extraterritorial application into ambiguous legislation might be one of the characteristics for which the Executive looks in its Supreme Court nominees.

\section{Welfare Effects of Extraterritorial Regulation through Litigation}

Finally, although this essay is anchored in positive political economy analysis, a brief note about the welfare effects of extraterritorial regulation, in particular regulation through litigation, is warranted. Political economy has its greatest salience when identifying public decisionmaking that reduces overall welfare.
There exist substantial reasons to believe that extraterritorial regulation effected through the litigation process does exactly this.

Regulation through litigation comprises two elements-prescriptive jurisdiction and adjudicative jurisdiction. Prescriptive jurisdiction involves the sovereign's decision to apply its rules to an offshore transaction. Adjudicative jurisdiction involves the court's ability to hear a case against a particular party, including nonresidents. Expansive prescriptive rules mean applying a local, presumably more stringent, rule to offshore conduct. Expansive adjudicative rules mean submitting offshore actors to U.S. litigation, whatever the substantive rule might be.

Alan Sykes has analyzed the welfare costs of litigation-based regulation. He observed that the extension of regulation through litigation does not result in universal application of the regime. Rather, the rules apply only to firms that engage in activities in the United States or own assets located there. Subjecting a subset of producers to a regulatory regime not imposed on others results is the functional equivalent of a trade barrier, which has well documented costs in terms of distorting production and sales decisions [51].

Sykes's argument focuses on prescriptive jurisdiction, but it can be extended to adjudicative jurisdiction. To the extent that defending in a U.S. courtroom is more costly than in a foreign court (due to unique practices such as civil jury trials, class action procedures, contingency fees arrangements for plaintiffs' attorneys, broad pretrial discovery, and access to punitive damages), broad adjudicative jurisdiction imposes costs on firms that enter the U.S. market. In deciding whether to compete in the U.S. market, foreign firms must take account of a set of procedural rules that function as a tax on doing business. Moreover, the tax is unique, because other civil litigation systems do not use these devices, or do so to a lesser extent.

Particular welfare arguments apply to delegating the decision whether to regulate extraterritorially to courts. Instability of domain rules-the determination of the scope of conduct to which a set of rules applies -has unambiguously negative effects (see cases cited in [47]). One can defend vagueness in standards that regulate primary conduct by arguing that postponing definition of legal requirements until application allows the regulator to exploit information that was hidden at the time of the standard's promulgation. No such argument applies to domain rules. Uncertainty about the applicable legal regime, as opposed to the particular rule governing primary conduct, only encourages opportunism by persons who, after the fact, find application of a particular regime beneficial.

The litigation mechanism by its nature produces vagueness and uncertainty about one particular domain question, namely the applicability of a regulatory regime to foreign conduct. As a normative matter, it has clear costs and dubious benefits. It thus appears 
that the persistence of this mechanism represents a classic public choice story, in which a homogenous and concentrated interest group (litigators) obtain rents but produce a net loss in social welfare.

\section{Conclusion}

In a world where changes in information and transportation technologies encourage the growth of transborder transactions, the question of extraterritorial regulation takes on greater salience. The issue has two dimensions: the policy question of whether to apply a regulatory regime extraterritorially, and the structural question of how to assign the authority to resolve the policy question. Political economy analysis can shed light on both of these dimensions.

This paper extends traditional political economy accounts of U.S. lawmaking by focusing on the distinct incentives surrounding Supreme Court and lower court decisionmaking. This extension provides

\section{References and Notes}

1. United States v. Aluminum Co. of America, 148 F.2d 416 (2d Cir. 1945) (case appealed directly from Southern District of New York to the Supreme Court, which referred the case to the Second Circuit because of a lack of a quorum of the Justices). For an effort by an influential private organization to codify the general principle of regulatory extraterritoriality, see American Law Institute, Restatement (Third) of the Foreign Relations Law of the United States $\S \S 402-04$ (1987).

2. A. Ahlström OY v. Commission (Joined Cases C89. 104, 116, 117, 125 to 129/85), [1988] E.C.R. 5193. The ECJ sought to disguise its embrace of extraterritorial regulation by asserting that the "implementation" of the alleged price-fixing cartel involved conduct on EC territory. Most observers have found it impossible to detect any difference between the European concept of "implementation" and the US concept of "effects".

3. Stephan PB. Global Governance, Antitrust, and the Limits of International Cooperation. Cornell International Law Journal. 2005;38(1):173-218.

4. EEOC v. Arabian American Oil Company, 499 U.S. 244 (1991). Two years later it backtracked a bit. Hartford Fire Ins. Co. v. California, 509 U.S. 764 (1993). See: Kramer L. Extraterritorial Application of American Law After the Insurance Antitrust Case: A Reply to Lowenfeld and Trimble. The American Journal of International Law. 1995;89(4):750-758.

5. Morrison v. Australia National Bank Ltd., 561 U.S., 130 S. Ct. 2869 (2010).

6. Kiobel v. Royal Dutch Petroleum Co., 569 U.S., 133 S. Ct. 1659 (2013).

7. The leading early cases are Filartiga v. PeñaIrala, 630 F.2d 876 (2d Cir. 1980) and Kadić v. Karadžić, 70 F.3d 232 (2d Cir. 1995). Recent cases that had reached an opposite conclusion include Sarei v. Rio an explanation for the Court's most recent high profile decisions in this area. It also points toward a normative assessment. It indicates that the tendency of Congress to tolerate, and of lower courts to embrace, judicial management of the decision whether to apply regulation extraterritorially almost certainly has significant welfare costs. The recent efforts of the Supreme Court to resist this tendency may reflect not only the particular political economy of the selection of justices, but also constrain those costs.

\section{Acknowledgements}

I am grateful to participants in a workshop at Duke University and to a panel discussion at the 2011 Annual Meeting of the American Political Science Association for comments and criticisms. I also would like to thank three anonymous referees for their helpful suggestions.

Tinto, PLC, 671 F.3d 736 (9th Cir. 2011), vacated and remanded, 133 S. Ct. (2013); Flomo v. Firestone Nat. Rubber Co., LLC, 643 F.3d 1013 (7th Cir. 2011) (dicta); Doe v. Exxon Mobil Co., 654 F.3d 11 (D.C. Cir. 2011); Abdullahi v. Pfizer, Inc., 562 F.3d 163 (2d Cir. 2009).

8. Trachtman JP. The Economic Structure of International Law. Cambridge, MA, USA: Harvard University Press; 2008.

9. Guzman AT. Choice of Law: New Foundations. Georgetown Law Journal. 2002;90(4):883-940.

10. My work, which employs political economy analysis in addition to welfare assessments, includes: Stephan PB. Regulatory Competition and Anticorruption Law. Virginia Journal of International Law. 2012;53 (1):53-70; Stephan PB. The Problem with Cooperation. In: Guzman AT, editor. Cooperation, Comity and Competition Policy; 2010. pp. 217-227; [3], supra note 3; Stephan PB. Institutions and Élites: Property, Contract, the State, and Rights in Information in the Global Economy. Cardozo Journal of International and Comparative Law. 2002;10(1):305-317; Stephan PB. The Political Economy of Conflicts of Laws. Georgetown Law Journal. 2002:90(4):957-970; Stephan PB. Choice of Law and Its Consequences: Constitutions for International Transactions. Brooklyn Journal of International Law. 2000;26(1):211-220; Regulatory Cooperation and Competition-The Search for Virtue. In: Bermann GA, Herdegen M, Lindseth PL, editors. Transatlantic Regulatory Cooperation: Legal Problems and Political Prospects; 2000. pp. 167-202.

11. For a general discussion of the comparability (in political economy terms) of rule-making through legislation and through litigation, see: Goetz $\mathrm{CJ}$, Brady G. Environmental Policy Formation and the Tax Treatment of Citizen Interest Groups. Law and Contemporary Problems. 1975;39(4):211-231.

12. Brewster R. Rule-Based Dispute Resolution in 
International Trade Law. Virginia Law Review. 2006;92 (2):251-288.

13. Brewster R. The Domestic Origins of International Trade Agreements. Virginia Journal of International Law. 2004;44(2):501-544.

14. Stephan PB. Accountability and International Lawmaking: Rules, Rents and Legitimacy. 1997:17(1): 695-697.

15. For the Byrd Amendment, see: Agriculture, Rural Development, Food and Drug Administration, and Related Agencies Appropriations Act of 2001, Pub. L. No. 106-387, §§ 1001-03, 114 Stat. 1549, 1549A-72 to $1549 \mathrm{~A}-75$, repealed by Deficit Reduction Act of 2005, Pub. L. No. 109-171, § 7601, 120 Stat. 4, 154. For the extension of Exon-Florio, see: Foreign Investment and National Security Act of 2007, Pub. L. No. 110-49, 121 Stat. 246. Although the direct effect of both these measures is to restrict imports, the trigger for the restrictions is overseas conduct. In the case of Byrd Amendment, the trigger was either overseas pricing of comparable goods or the receipt of subsidies by a foreign producer. In the case of the Exon-Florio regimes, one of the concerns about foreign investment is access to domestic national security secrets that will lower overseas production costs.

16. There is significant and suggestive research on the correlation of judicial voting behavior and the party affiliation of the nominating President. E.g.: Yung CR. Beyond Ideology: An Empirical Study of Partisanship and Independence in the Federal Courts. George Washington Law Review. 2012;80(2);505567; Fischman JB. Estimating Preferences of Circuit Judges: A Model of Consensus Voting, Journal of Law and Economics. 2011;54(4):781-809; Fischman JB, DS Law. What Is Judicial Ideology, and How Should We Measure It? Washington University Journal of Law \& Policy. 2009;29(1):133-214; Cameron CM, Park J-K, Beim D. Shaping Supreme Court Policy Through Appointments: The Impact of a New Justice. Minnesota Law Review. 2009. 93(5):1820-1870; Daniel R. Pinello. Linking Party to Judicial Ideology in American Courts: A Meta-Analysis. The Justice System Journal. 1999;20(3):219-254; Cross FB, Tiller EH. Judicial Partisanship and Obedience to Legal Doctrine: Whistleblowing on the Federal Courts of Appeals. Yale Law Journal. 1998;107(7):2155-2176; Revesz RL. Environmental Regulation, Ideology, and the D.C. Circuit. Virginia Law Review. 1997;83(7):1717-1772. None of these studies, however, attempts to identify or measure any differences in this correlation as a function of the judge's place in the federal hierarchy.

17. Voigt S. Empirical Constitutional Economics: Onward and Upwards? Journal of Economic Behavior \& Organization. 2011;80(2):319-330.

18. Securities Exchange Act of 1934, § 10(b), 48 Stat. 881, 891.

19. 17 C.F.R. § $240.10 b-5$.

20. For a skeptical account of these events that nonetheless accepted the implied private right of action as a fait accompli, see: Blue Chip Stamps v. Manor Drug Stores, 421 U.S. 723, 729-30 (1975).

21. 405 F. 2d 200, modified on other grounds en banc, 405 F. 2d 215 (2d Cir 1968).

22. Leasco Data Processing Equip. Corp. v. Maxwell, 468 F. 2d 1326 (2d Cir. 1972).

23. Bersch v. Drexel Firestone, Inc., 519 F. 974 (2d Cir. 1975).

24. IIT v. Vencap, Ltd., 519 F. 2d 1001 (2d Cir. 1975).

25. Within days Congress appeared to have modified Morrison so as to allow the Department of Justice and the Securities and Exchange Commission, but not private litigants, to bring suits based on foreign conduct that satisfied either the effects or conduct tests. For discussion of this enactment, embodied in the Dodd-Frank Wall Street Reform and Consumer Protection Act, see [40].

26. A representative sample of other cases where the modern Supreme Court reined in litigation-friendly lower courts includes: Janus Capital Group, Inc. v. First Derivative Traders, 564 U.S., 131 S. Ct. 2296 (2011); Stoneridge Investment Partners, LLC v. Scientific-Atlanta, Inc., 552 U.S. 148 (2008); Sosa v. AlvarezMachain, 542 U.S. 692 (2004); F. Hoffmann-La Roche Ltd. v. Empagran S.A., 542 U.S. 155 (2004); Gonzaga University v. Doe, 536 U.S. 273 (2002); Correctional Services Corp. v. Malesko, 534 U.S. 61 (2001); Alexander v. Sandoval, 532 U.S. 275 (2001); Sale v. Haitian Centers Council, 509 U.S. 155 (1993); EEOC v. ArabianAmerican Oil Co., 499 U.S. 244 (1991); Middlesex County Sewerage Auth. v. Nat'l Sea Clammers Ass'n, 453 U.S. 1 (1981); California v. Sierra Club, 451 U.S. 287 (1981); Pennhurst State Sch. \& Hosp. v. Halderman, 451 U.S. 1 (1981); Universities Research Ass'n v. Coutu, 450 U.S. 754 (1981); Touche Ross \& Co. v. Redington, 442 U.S. 560 (1979); Blue Chip Stamps v. Manor Drug Stores, 421 U.S. 723 (1975).

27. The details of the historical background are unimportant for our purpose. For discussion, see: Sosa v. Alvarez-Machain, 542 U.S. 692, 712-14 (2004); Filartiga v. Pena-Irala, 630 F.2d 876 (1980); For the scholarly case against extraterritoriality, see: Bellia Jr. AJ, Clark BR. The Alien Tort Statute and the Law of Nations. The University of Chicago Law Review. 2011;78(2):445-552.

28. The statute in question, codified at 28 U.S.C. $\S 1350$, gives the federal district courts "original jurisdiction of any civil action by an alien for a tort only, committed in violation of the law of nations or a treaty of the United States".

29. Sosa, note 23 supra, at 731-33. To be technical, the Sosa Court ruled that the statute did not directly adopt any tort rules, but rather presupposed that they existed and that federal courts had the authority to develop them. The Court admonished the lower courts to create tort law with respect to only a narrow range of international obligations. The lower courts, however, found that this limited range extended to many situations, and dozens of suits survived initial motions to dismiss. See [7]. 
30. Kiobel v. Royal Dutch Shell Co., 133 S. Ct. at 1669.

31. Kiobel v. Royal Dutch Shell Co., 133 S. Ct. at 1671 (Breyer J, dissenting). As a technical matter, most cases involving an alien plaintiff and a U.S. defendant would fall within the diversity jurisdiction of the U.S. judiciary, regardless of the substantive law that might apply. The dissenters' formulation, however, would allow federal courts to create international human rights law, rather than looking to state or foreign law to apply to the tort claim.

32. 26 U.S.C. §§ 61; 26 C.F.R. § 1.1-1(b). Hong Kong on occasion has used this approach, but to my knowledge no other jurisdiction does.

33. 26 U.S.C §§ 951-964.

34. Foreign Trade Antitrust Improvements Act of 1982, 96 Stat. 1233, 1246, codified qt 15 U.S.C. § $6 a$. One might wonder why Congress clarified and to some modest extent limited the Sherman Act's extraterritoriality, given the assumptions made in the rudimentary model discussed above. One plausible refinement is that Congress balanced the interests of domestic firms that operated overseas with those of domestic firms that only face import competition. The latter might wish for stronger extraterritoriality, but the former most likely want some clarity about their legal exposure for their overseas activities. The legislation can be seen as a compromise between these interests.

35. Simplifying considerably, the FCPA applies to issuers (within the terms of U.S. securities laws) and their agents as well as U.S. subjects and their agents. Foreign issuers and their agents and the foreign agents of U.S. persons also have to satisfy an extremely loose instrumentality-of-interstate-commerce test, while U.S. issuers and U.S. persons do not. In addition, since 1998 foreign persons are regulated if they use an instrumentality while on U.S. territory to violate the substantive provisions of the Act. Foreign Corrupt Practices Act of 1977, Pub. L. No. 95-213, Title I, § 104, 91 Stat. 1496 (1977), amended by Omnibus Trade and Competitiveness Act of 1988, Pub. L. No. 100-418, Title V, $\S$ 5003(c), 102 Stat. 1419 (1988); Violent Crime Control and Law Enforcement Act of 1994, Pub. L. No. 103-322, Title XXXIII, § 330005, 108 Stat. 2142 (1994); International Anti-Bribery and Fair Competition Act of 1998, Pub. L. No. 105-366, § 3, 112 Stat. 3304 (1998).

36. 499 U.S. 244, 258-59 (1991).

37. Section 109 of the Civil Rights Act of 1991 extends Title VII to cases where a U.S. citizen suffers discrimination in overseas employment, but only if the employer is a U.S. person or controlled by a U.S. person, and if application of Title VII does not violate local law.

38. See [13]. One might object that this involved only an import tax, but, as noted above, the conduct that triggered the tax (which the statute converted into a bounty for domestic plaintiffs) was extraterritorial, namely selling goods outside the United States at a higher price than their import price or accepting production subsidies from foreign governments.
39. Trade Act of 1974, P.L. 93-618, Title III, as amended by Omnibus Trace and Competition Act of 1988, P.L. 100-418, Title I, Subtitle C, 102 Stat. 1164, and Uruguay Round Agreements Act of 1994, P.L. 103-465, Title III, 108 Stat. 4939, 4993, codified at 19 U.S.C. §§ 301-10. These sanctions apply only to imported goods, but they function as retaliation for extraterritorial acts of foreign states.

40. Dodd-Frank Wall Street Reform and Consumer Protection Act, Pub. L. 111-203, 929P(b), 124 Stat. 1864. I say "apparently" because, as afficionados know, the statutory language does not address the case's holding. Morrison read Section 10(b), and therefore Rule 10b-5, as nonextraterritorial in application. Section 929P(b), however, gives jurisdiction to the courts to hear claims under $10(\mathrm{~b})$ based on territorial conduct or effects, but does not modify 10(b) itself. In other words, the legislation creates federal court jurisdiction to hear a set of cases that, according to Morrison, has no elements. See: Painter RW. The DoddFrank Extraterritorial Jurisdiction Provision: Was It Effective, Needed or Sufficient? Harvard Business Law Review. 2011;1(1):195-230. I suspect that the courts will forgive this confusion between prescriptive and adjudicatory jurisdiction, but perhaps they will not.

41. As to public enforcement, the statute revives the vague direct-effects-or-substantial-conduct test, giving the courts some role in determining the precise extent of extraterritorial jurisdiction. Public sanctions, however, can be less consequential than the potential liability generated by class actions on behalf of large numbers of securities market participants.

42. Aronson PH, Gellhorn E, Robinson GO. A Theory of Legislative Delegation. Cornell Law Review. 1982;68(1):1-67.

43. Pasquantino v. United States, 544 U.S. 349, 354 n. 1 (2005) (reserving issue).

44. Norex Petroleum Ltd v. Access Industries, Inc., 631 F.3d 29 (2d Cir. 2010) (no extraterritoriality in light of Morrison).

45. Liquidation Comm'n of Banco Intercontinental, S.A. v. Renta, 530 F.3d 1339 (11th Cir. 2009) (applies extraterritorially).

46. Poulos v. Caesars World, Inc., 379 F.3d 654 ((9th Cir. 2004) (applying pre-Morrison securities law precedent by analogy).

47. Stephan PB. Privatizing International Law. Virginia Law Review. 2011;97(7):1573-1664.

48. Brief for the United States as Amicus Curiae Supporting Respondents, Morrison v. Australia Bank Ltd., No. 09-1191.

49. Kiobel v. Royal Dutch Shell Co., 133 S. Ct. at 1668 (noting change in position).

50. Brief for the United States as Amicus Curiae Supporting Petitioners, F. Hoffman-LaRoche Ltd. V. Empagran S.A., No. 03-724.

51. Sykes AO. Transnational Forum Shopping as a Trade and Investment Issue. Journal of Legal Studies. 2008;(2):339-378. 